\title{
MARKETING TOURISM IN THE DIGITAL ERA AND DETERMINANTS OF SUCCESS FACTORS INFLUENCING TOURIST DESTINATIONS PREFERENCES
}

\author{
Mbarek Rahmoun $^{1 *}$ and Yasser Baeshen ${ }^{2}$ \\ ${ }^{1}$ Faculty of Applied Studies, \\ King Abdulaziz University, Kingdom of Saudi Arabia. \\ ${ }^{2}$ Faculty of Economics and Administration (FEA), \\ King Abdulaziz University, Kingdom of Saudi Arabia
}

\begin{abstract}
Tourism development has economic benefits, but there also issues related to complex digital marketing and environmental impacts. Nowadays, customers want fast, accurate and friendly responses from the tourism agencies. Hence, the industry must be able to cope with the demands from the clients by using the latest digital technology. Moreover, economic and environmental sustainability are also essential for the long-term tourism resource management. Therefore, this paper explores sustainable tourism in relation to consumer preferences, which ultimately determines economic implications in terms of net value, contributed capital, and employment. Based on the surveys conducted on 75 travel agencies in Europe, it was found that the key factors to destination preferences are (in descending order): customers' income $(67.7 \%)$, the exchange rate $(63.9 \%)$, digital marketing factors $(53.4 \%)$, respect for the environment $(38.6 \%)$, and sports activities (33.3\%).
\end{abstract}

Keywords: tourism, trip, destination, environment, sport, consumer income

\section{ARTICLE INFO}

\section{Article History:}

Received: 14 November 2020

Accepted: 25 February 2021

Published: 30 April 2021

* Corresponding Author: Mbarek Rahmoun. E-mail: mbarekrahmoun@yahoo.fr 


\section{INTRODUCTION}

Previous studies on development models have highlighted the importance of tourism as a source of income and employment. It also provides macroeconomic and financial benefits not only to the national economies but also to the local communities. While monetary improvement and the potential for work are commonly the fundamental resources for tourism with a view to regional advancement, the conceivable outcomes of economic utilization to maintain and upgrade natural and social resources should not be neglected. The determinants of global tourism streams have been the subject of various studies by Lim (1997), Khan et al. (2020), and Čerović et al. (2015). Financial and social determinants, for example, genuine salary and relative costs, are frequently used to clarify tourism impacts. There is also new lifestyle and sustainable tourism like 'nature-based tourism', 'ecotourism' and 'cultural tourism' (Čerović et al., 2015; Hayley, 2020).

\section{DIGITAL MARKETING AND FACTORS INFLUENCING TOURIST DESTINATION PREFERENCES}

The World Tourism Organization (UNWTO) classifies tourism into two main categories; personal and business purposes (2007). The purposes can be further classified into subcategories such as holidays, leisure, and recreation; visiting friends and relatives; education and training; health and medical care; religion and pilgrimages; shopping; and other pursuits. Tourism used to be based on pleasure as people preferred to see and explore new places by themselves. However, this situation has changed dramatically due to digital marketing and new advertisement methods.

\section{Social and Sustainability Impacts of Tourism}

The digital saturation of services has given communications companies the potential for exceptional capabilities (companies reach out to the individual in all aspects of their life). According to Behnassi (2008), tourism comprises a chance for nations beset with destitution and joblessness to generate employment and income for regional and national socio-economic development, but the management of tourism development determines its outcomes, including the potential for both positive and negative impacts. 
Tourism entails more demand for natural and human resources, with profound implications for the environment. Developing countries are particularly prone to the negative effects of tourism due to their prioritization of short-term economic gains, at the expense of long-term economic and environmental sustainability (UNWTO, 2020). Tourists generally seek various kinds of leisure activities, for diverse purposes, including natural beauty, sports activities, a more amenable climate, or heritage tourism. Attracting tourists is the core economic motor of the tourism industry, and tourism products and services must be managed and marketed appropriately for a successful and sustainable tourism industry (Femenia et al., 2019).

\section{Socio-Cultural Impacts of Tourism}

Multi-cultural societies have many impacts on tourists for the fact that tourists are attracted to new different experiences such as new cultures, new civilizations, and new traditions from all over the world.

It is generally believed that tourism activities significantly change the eventual fate of the community, at times more than other economic activities. The advancement of universal tourism, especially when it happens between Western and East countries is undoubtedly a central point of cultural change, thus affecting the community of the destination countries.

Institutionalization is associated with scenery, convenience, food and drink, related to the longing of tourists to discover unmistakable components in a new situation, for example restaurants and hotels. The engagement of visitors with locales is mediated by the tourism experience, with varying degrees of fidelity to the integrity of local communities. Generally, tourists are happy with a cursory look at the nearby climate and way of life, and are more focused on their hedonic activities. Tourism management must seek to satisfy tourist needs, continually advancing products offered to satisfy the changing demands of their clients. Excesses can occur at the social level when the breaking points of progress relative to the social framework of local communities are reached (Femenia et al., 2019).

Financial inequality can create power imbalances and socio-economic disruption among local communities. A sudden surge in tourism income from tourist can disrupt local economies and cause long-term economic 
problems (such as the decline of agricultural production due to people seeking higher-paid employment in unsustainable tourism industries). This is aside from the negative aspects of tourism in general, such as a tendency towards gambling, nightclubbing, and prostitution that can undermine the social fabric of traditional communities especially in developing countries.

\section{Tourism and Digital Marketing}

The digital revolution is radically changing the world we live in. New digital technologies have introduced important innovations in factories, hospitals, hotels, cities and territories. Marketing is significant for any types of businesses since it has a crucial contribution to the achievement of several successful businesses. Production and supply processes eventually depending on the promotional activities. Advertising can be characterized as the way towards presenting and advancing products and services into the market to attract customers. With the developing number of items and administrations, business organizations have been compelled to think of new strategies to market their products. It is on this premise that e-advertising has been used by organizations to upgrade deals. This has been facilitated by the development of the internet.

The entire world is absolutely reliant on novelties, and in the presentday world it is vital to be exceptional. However, simply the awareness of the new patterns alone is not sufficient. Studies shown that there has been a late leap forward in marketing innovations within the tourism industry. As customers are generally attempting to acquire financial and experiential advantages via tourism, it is vital for the players in the industry to make full use of the advance technology in marketing. For instance, online networking involves an enormous assortment of instruments that make it feasible for their clients to share, trade or post media documents and different kinds of data using different channels onto the web. Fundamentally, the development of e-marketing has just come about into huge movements from the shopper and supplier sides. Purchasers turned out to be progressively refined regarding looking for the most reasonable alternatives in settlement, flights and different issues (Femenia et al., 2019). 


\section{Reasons behind usage of digital marketing in tourism}

More customer engagement: Dealing with customers have never been easier. You can connect with them regardless of where they are in the world. You can find out about what your clients expect even before they use your services, you can draw in with them during and after the delivery of services. Happy and friendly dealt clients will later become returning customers and will recommend others to you.

Exposure on search engine results: It is admitted that, Google, Bing, Yahoo, and other web indexes or engines have recorded us so often asking, "where is the best spot to travel?". This being stated, it is just appropriate for individuals in tourism when making the tourism industry to guarantee that they put resources into search engine optimization strategies to get their site up on the primary outcomes page. For some, organizations, search engines and search positioning has become the most significant achievement factor (Gelter, 2017)

Growing number of experience hungry consumers: Traveling has never been easier and less expensive in human history. Inaccessible destinations that could be seen only in films would now be reached within hours of flight. An ever-increasing number of individuals are traveling out to find different cultures and to see things that they have never experienced before. Video blogs and live recordings can be used to show the genuine experience of other tourists. Individuals would now be able to remain in their bed rooms and watch a person eating Pho in Vietnam or doing Bungee jumping in Canada and that boosts them to immerse themselves in the experience (Gretzel et al., 2015)

Personalized travel experience: Digital marketing and computerized tools efficiently allow you to gather and investigate your information. With a streamlined channel, you can gather all the clients to connect with you through the business pipeline and the services term. The gathered information can be investigated to permit you to offer a customized understanding for your customers for a bigger scope just as recognizing designs that could adversely affect your administration. You will at that point have the option to comprehend your clients better and give them what they are genuinely looking for in their next movement or traveling. 
Current digital marketing trends in tourism: Numerous organizations have appreciated incredible triumphs by putting resources into digital marketing. Regardless, of whether you are a ticketing office, a lodging reservation organization, a booking organization for cafés and bars or a movement bundle supplier, you that you can utilize advanced advertising in a manner or two. Regardless, of whether you will be fruitful all relies upon the manner in which you plan and execute your procedure. An accomplished advanced advertising organization can unquestionably push you to appropriately design and get things ready for action, yet at last, everything depends on your exertion and responsibility into making digital marketing work for you.

Social media and tourism industry: Social media systems have revolutionized the industry. In addition, social media make it conceivable to spread data considerably quicker and with less expense. The informal exchange has been demonstrated as a powerful method to advance organizations and a few viral advertising strategies have been created so as to connect with the web users. The web-based social networking systems are important apparatuses for organizations that have a place with the travel industry since they can assist them with advancing their administrations with less expense, grab users attention and above all produce buzz around their brands, services or travel destinations. With a large number of web locales, interpersonal organizations, web based booking engines and survey sites, vacationers and guests would now be able to pick and choose where they need to remain, how they need to spend their excursions or vacations and discover most recent the travel industry pictures and recordings that represents the experience and constant perspective on the destinations

\section{Environmental Impacts}

The effects of tourism are various, huge, and complex. Tourism advancement has for sure previously debased numerous environments. Especially in coastal and mountain areas known for their vulnerability, which has become increasingly incongruent with the logic of feasible and manageable improvement. However, ecotourism promises to reverse the traditional negative impacts of tourism on the environment by offering sustainable tourism experiences with long-term affects to promote ecological wellbeing in tourism destinations, alongside economic benefits for local communities and governments (Ellyard, 2006; UNWTO, 2020). 
All restoration projects are fueled by cash, as are politics and executive decisions across the board. If a government is not supportive of a tourism project, no advancement can be made. This is particularly essential when choices must be made about using common assets. The primary political concern in many latently attractive tourism destinations is deforestation, such as the unblemished tropical rainforest of Costa Rica. Ecotourism offers an income source for such countries, for local communities and the national economy, while safeguarding the integrity of the environment. Furthermore, tourism is greatly increased by the side effects of globalization, which can lead developing nations to advance in their monetary and political issues. This frequently incorporates higher sanitation and supportability benchmarks over all sectors, thus tourism in itself can promote some aspects of socio-economic development due to the demands and expectations of international tourists. This part of tourism is substantially more promoted and has more open support than the socio-cultural aspect (Moreo et al., 2018; TEQSA, 2019; The-Ice, 2019). Biodiversity is fundamental for sustainable economic prosperity and human life on this planet. Biodiversity is being shockingly attacked by human economic processes. The loss of biodiversity and the weakening of biological systems is caused primarily via land spread transformations, contamination, unfeasible abuse of regular assets, the presentation of intrusive species, and the impacts of environmental change. Many of the most biodiverse regions of the planet are the most susceptible to the negative environmental impacts of globalization and global warming, yet they also hold great appeal for tourists. Rapid increases in tourism development can be catastrophic for local environments, particularly in terms of deforestation and the evaporating of wetlands. Such unsettling influences lead to an irreversible loss of biodiversity, inconsistent with the arrangements of the UN Convention on Biodiversity (Brüggemann et al., 2001). Numerous environmental issues affect the tourism industry, including increased tourist volume, environmental devastation, and the breakdown of land-ocean progression; the most noticeable outcomes of rapid construction in coastal regions for tourism resorts lead to sand extraction, erosion of sea shores and dunes, and soil debasement, all of which reduce biodiversity and scenic quality (Hooper et al., 2005; Femenia et al., 2019; UNWTO, 2020).

\section{Contribution of Tourism to Environmental Conservation}

Financial: The travel industry can contribute directly to the preservation of sensitive zones and living spaces. Income from park 
extra charges and identical sources can be assigned explicitly to pay for ecologically beneficial projects. Uncommon expenses for park tours or preservation activities can be gathered from travelers or tour operators.

Contribution to government incomes: A few governments gather cash in more circuitous forms from general revenue levied from tourismassociated businesses (e.g. hotels and restaurants). Client charges, personal duties, and permit expenses for exercises (e.g. fishing licenses) include direct sources of income. Such assets can generate far more income than their overhead costs, such as park officer compensations and park support, and can also be directed to larger environmental protection projects.

Improved environmental management and planning: More developed ecological systems can be significant devices for arranging and working in the travel industry offices in a way that limits their natural effects. For instance, green structure (using vitality proficient and non-contaminating development materials, sewage frameworks, and energy sources) is an inexorably significant way for the travel industry to diminish its effects on the environment. In addition, in light of the fact that waste treatment and disposal are frequently major, long-term natural issues in the travel industry, contamination avoidance, and waste minimization strategies are particularly significant for tourism.

Raising environmental awareness: The travel industry can possibly increase estimation and appreciation about the environment through spreading mindfulness and awareness of ecological issues when it carries individuals into closer contact with nature and the earth. Tourism must consolidate the standards and practices of economical usage by actually incorporating the building of consumer interest in their tourist products and offerings, such as by using cleaner production approaches, with services that limits ecological effects. The travel industry can assume a crucial key role in giving environmental data and increasing awareness among tourists of the ecological results of their activities. Visitors and travel industryrelated organizations latently consume a huge amount of products and services; skewing consumption toward those produced and provided in an ecologically sustainable way can have a tremendous positive impact on the planet's condition (Zheng et al., 2020; Yu et al., 2020). 
The goal of sustainable tourism is not simply to amplify the effects of the nearness of tourism, which can be counter-productive to biological and socio-cultural goals, but to think in terms of "positive biodiversity" and, in specific cases and spots, assume activities to maintain and advance nearby biological systems, or advance neighborhood cultures, which are often a wellspring of pride for the population. Historically, normal assets have been utilized by people for supply administrations, either legitimately for their food, wellbeing, or vitality needs (through angling, creature farming, agribusiness, ranger service, extraction of gas, metals, and so forth), or in a roundabout way as elements of generation of a preparing industry, for utilization in different products and services.

To be really viable from a natural perspective, tourism management for the protection and tourist utilization of ecological resources must approach a worldwide way to deal with payment for ecological services, which comprises an intentional exchange during which the environmental administration (for usage of the land that facilitates tourism) is duly compensated. Services must give an appropriately estimated incentive for the safeguarding of biodiversity, assuming responsibility for the biological system administration - and co-benefits, including socio-cultural services of benefit the local communities. People are happy to pay ecological components to keep on existing, regardless of whether these individuals legitimately use these services (Tse et al., 2002).

\section{Exchange Rate Impacts}

Previously, things were very different from now. The rate of tourism used to be lower than nowadays. Since people have become more interested to discover new world, thanks to many reasons such as internet announcement and social media in general. With respect to the connection between tourism and exchange rate, a few experimental examinations find that the conversion scale profoundly affects the tourism industry. It is highly sensitive to exchange rates, which ultimately determines the amount of cash international tourists spend into local economies, and the attraction of local destinations in the international tourism market is largely determined by exchange rates under the basic supply-and-demand paradigm (i.e. tourists are attracted to the best quality for the lowest price, which is facilitated by lower-value currencies relative to tourists' home currency). Chaiboonsri et 
al. (2009), utilizing a board information model, studied India over quarterly periods from 2002 to 2006 , and found that exchange rates negatively affect tourism arrivals in India; however, they found that it positively affected arrivals in Thailand over the period 1986-2007.

Kareem (2008) applied the Dynamic Summed -up Minutes Model (GMM) to African nations, reasoning that the valuation for the conversion scale and swelling negatively affect vacationer appearances in Africa. Moreover, Algieri and Kanellopoulou (2008) showed through a regress model applied for quarterly information from 1985 to 2006 that genuine conversion standards are a fundamental factor to push tourism receipts in France and Spain. Bashagi and Muchapondwa (2009) utilized the ARDL approach to distinguish the exchange rate among variables that impact global tourism interest for Tanzania, Hong Kong, and Singapore, finding that the costs of tourism products, the expense of movement, aggressive costs, the exchange rate, and tourism incomes and tourism inclinations are all potential determinants of visitor appearances for Tanzania.

According to Mohamed (2015), most research on the impact of exchange rates on worldwide visitor streams has focused on the impacts of exchange rate systems (Adam \& Cobham, 2007), analyzing tourism demands relative to such systems (Gil-Pareja et al., 2007), and finding the relationship significant in determining universal traveler streams. It is clearly obvious that a legislature would not pick an exchange rate strategy exclusively based on whether one conversion scale system or the other would profit tourism the most, yet it is additionally obvious that information on the degree to which the tourism area responds to elective swapping scale systems gives incredibly important data to leaders (Femenia et al., 2019)

The conversion standard is an extra marker that must be used reliably in the demonstrating of tourism request. Genuine financial elements have a critical informative force in deciding worldwide tourist streams. The potential effect of swapping scale systems in different structures on the volume of universal traveler appearances is still emphatically considered. With respect to the idea of a swapping-scale system, it ought to be noticed that this is the approach forced on money by its giving nation in connection to different monetary forms and the outside trade advertise, in this manner influencing the degree of trade rates. 


\section{Sport Impacts}

Sport is particularly associated with tourism in terms of activities engaged in by many tourists, and travelling to view professional sports, particularly major events (e.g. world cups or athletics competitions). The impacts of sport on tourism have been studied using experimental methodologies dependent on the redundancy of perceptions, uses, items, and the idea of experience. While that inspiration contemplates customer base investigation, the contribution of socio-cultural styles and typologies are clearly relevant, and we should not dismiss the way that they observe circumstances and interpret changes more than some other things. The usage of perception instruments ought not to obscure their breaking points (Pigeassou, 2002). Table 1 summarizes the classic conceptualization of sport tourism in tourism research.

Table 1: Definition of Sport Tourism

\begin{tabular}{|c|c|c|c|}
\hline De Knop (1987) & $\begin{array}{l}\text { A person who practices } \\
\text { competitive sport activities } \\
\text { during a vacation }\end{array}$ & $\begin{array}{l}\text { Redmond (1990, } \\
\text { 1991) }\end{array}$ & $\begin{array}{l}3 \text { usage types: } \\
\text { - Observer of sport } \\
\text { events } \\
\text { - Active participation in } \\
\text { sport activities } \\
\text { - Visitor of sport cultural } \\
\text { elements }\end{array}$ \\
\hline De Knop (1990) & $\begin{array}{l}\text { A sport activity } \\
\text { Participating in sports or } \\
\text { recreational activities using } \\
\text { the possibilities offered } \\
\text { (facilities, services) at the } \\
\text { holiday location } \\
\text { Occasionally participate } \\
\text { in sports or recreational } \\
\text { activities not organized at } \\
\text { the holiday location }\end{array}$ & Hall (1992) & $\begin{array}{l}2 \text { usage types: } \\
\text { - Travelling in order to } \\
\text { watch the competitive } \\
\text { activity } \\
\text { - Travelling to } \\
\text { participate in a sport } \\
\text { or Ludo sport setting }\end{array}$ \\
\hline $\begin{array}{l}\text { Nogawa et al. } \\
\text { (1996) }\end{array}$ & $\begin{array}{l}3 \text { usage types: } \\
\text { Traveling to take part in a s } \\
\text { Travelling to participate in s } \\
\text { Travelling to participate in s }\end{array}$ & $\begin{array}{l}\text { port event } \\
\text { self-organized sport a } \\
\text { self-organized sport a }\end{array}$ & $\begin{array}{l}\text { ctivities } \\
\text { ctivities }\end{array}$ \\
\hline \multicolumn{4}{|c|}{ Definitions based on the observation of the characteristic productions of sports tourism } \\
\hline \multicolumn{4}{|c|}{$\begin{array}{l}5 \text { main product categories: } \\
\text { Sports tourism targeted at the use of sports attractions } \\
\text { Sports tourism stays in centers, resorts or recreational or sports training camps } \\
\text { Cruises with a sport target whose object is practicing sports, meeting sportspeople or, } \\
\text { visiting sport areas } \\
\text { Sports tourism trips for practicing several sport activities: golf, tennis, hiking, safari, trekking } \\
\text { Sports tourism during an event. regional, national or international }\end{array}$} \\
\hline
\end{tabular}


This study includes the following five hypotheses:

H1: The most decisive criterion for visiting a country is respect for the environment

H2: Digital marketing factors positively affect tourism destination preference

H3: Exchange rate positively affects tourist destination preference

H4: Sport positively affects tourist destination preference

H5: Consumer income positively affects tourist destination preference

\section{RESEARCH METHODOLOGY}

We rigorously chose each question based on a review of previous literature, and defined precisely what the question is trying to find out, and then we compiled the questionnaire using simple and unambiguous terms. The questions written were neutral and not leading. Quota sampling is defined as a non-probability sampling method in which researchers create a sample involving individuals that represent a population. For this research, we used the quota method, starting with one or more filter questions intended to eliminate people not concerned by the questionnaire. This study explored opinions among a sample of 75 travel agencies in Europe. A quantitative research design was adopted. We retained a stratified sampling procedure, as the list of travel agency was available. We chose a sample of 75 agencies that have clients who travel to destinations in European countries. To confirm and validate the four hypotheses, the questionnaire was administered to this population to explore their views concerning leisure travel.

The questions in the questionnaires were answerable with five-point Likert scale: 1- strongly disagree, 2- disagree, 3-indifferent, 4- agree, 5strongly agree.

\section{RESULTS}

\section{Digital Marketing}

Table 2 shows that $38.7 \%$ of the respondents agree that the digital marketing tools are important for them to visit a country, and $14.7 \%$ totally 
agree. In total $53.4 \%$ believe that the digital marketing tools are important for them to travel to a country.

Table 2: Digital Marketing

\begin{tabular}{cccccc}
\hline & & Frequency & Percent & Valid Percent & $\begin{array}{c}\text { Cumulative } \\
\text { Percent }\end{array}$ \\
\hline Valid & 1.00 & 10 & 13.3 & 13.3 & 13.3 \\
& 2.00 & 10 & 13.3 & 13.3 & 26.7 \\
& 3.00 & 15 & 20.0 & 20.0 & 46.7 \\
& 4.00 & 29 & 38.7 & 38.7 & 85.3 \\
& 5.00 & 11 & 14.7 & 14.7 & 100.0 \\
& Total & 75 & 100.0 & 100.0 & \\
\hline
\end{tabular}

\section{Environmental}

Table 3 shows that $25.3 \%$ of the interviewees agree that the criterion of environmental respect policy being applied by the country of destination is considered important for them to visit a country, and $13.3 \%$ totally agree. In total $38.6 \%$ believe that the factor of respect for the environment is important for them to travel to a country.

Table 3: Respect of the Environment

\begin{tabular}{cccccc} 
& & Frequency & Percent & Valid Percent & $\begin{array}{c}\text { Cumulative } \\
\text { Percent }\end{array}$ \\
\hline Valid & 1.00 & 11 & 14.7 & 14.7 & 14.7 \\
& 2.00 & 23 & 30.7 & 30.7 & 45.3 \\
& 3.00 & 12 & 16.0 & 16.0 & 61.3 \\
& 4.00 & 19 & 25.3 & 25.3 & 86.7 \\
& 5.00 & 10 & 13.3 & 13.3 & 100.0 \\
& Total & 75 & 100.0 & 100.0 & \\
\hline
\end{tabular}

\section{Exchange Rate}

Table 4 shows that $36 \%$ of the interviewees agreed that the exchange rate criterion is considered important for them to visit a country, and $25.3 \%$ strongly agreed. In total, $63.9 \%$ believed that the exchange rate factor is important for them to travel to a country. 
Table 4: Exchange Rate

\begin{tabular}{cccccc} 
& & Frequency & Percent & Valid Percent & $\begin{array}{c}\text { Cumulative } \\
\text { Percent }\end{array}$ \\
\hline Valid & 1.00 & 11 & 14.7 & 14.7 & 14.7 \\
& 2.00 & 8 & 10.7 & 10.7 & 25.3 \\
& 3.00 & 10 & 13.3 & 13.3 & 38.7 \\
& 4.00 & 27 & 36.0 & 36.0 & 74.7 \\
& 5.00 & 19 & 25.3 & 25.3 & 100.0 \\
& Total & 75 & 100.0 & 100.0 & \\
\hline
\end{tabular}

\section{Sport}

Table 5 shows that the sport criterion is viewed as an important criterion by a total of $33.3 \%$ of the samples.

Table 5: Sport

\begin{tabular}{cccccc}
\hline & Frequency & Percent & Valid Percent & $\begin{array}{c}\text { Cumulative } \\
\text { Percent }\end{array}$ \\
\hline Valid & 1.00 & 11 & 14.7 & 14.7 & 14.7 \\
& 2.00 & 12 & 16.0 & 16.0 & 30.7 \\
& 3.00 & 12 & 16.0 & 16.0 & 46.7 \\
& 4.00 & 24 & 32.0 & 32.0 & 78.7 \\
& 5.00 & 16 & 21.3 & 21.3 & 100.0 \\
& Total & 75 & 100.0 & 100.0 & \\
\hline
\end{tabular}

\section{Consumer Income}

Table 6 shows that $57 \%$ of the samples agree that the consumer rate criterion is considered important for them to visit a country, and $10.7 \%$ completely agree that their budget is important for choosing a similar destination. In total, $67.7 \%$ confirm that the consumer income factor is important for them to travel to a country. 
Table 6: Consumer Income

\begin{tabular}{cccccc} 
& & Frequency & Percent & Valid Percent & $\begin{array}{c}\text { Cumulative } \\
\text { Percent }\end{array}$ \\
\hline Valid & 1.00 & 1 & 1.3 & 1.3 & 1.3 \\
& 2.00 & 5 & 6.7 & 6.7 & 8.0 \\
& 3.00 & 18 & 24.0 & 24.0 & 32.0 \\
4.00 & 43 & 57.3 & 57.3 & 89.3 \\
& 5.00 & 8 & 10.7 & 10.7 & 100.0 \\
Total & 75 & 100.0 & 100.0 & \\
\hline
\end{tabular}

\section{Validation of Hypotheses}

According to $\mathrm{R}$ Square score, the key variables explain more than $70 \%$ of tourist destination preference (Table 7). Testing for the validation of hypotheses is shown in Table 8 and discussed below.

Table 7: Model Summary

\begin{tabular}{|c|c|c|c|c|c|c|c|c|c|}
\hline \multirow[b]{2}{*}{ Model } & \multirow[b]{2}{*}{$\mathbf{R}$} & \multirow[b]{2}{*}{$\begin{array}{c}R \\
\text { square }\end{array}$} & \multirow[b]{2}{*}{$\begin{array}{l}\text { Adjusted } \\
\text { R square }\end{array}$} & \multirow{2}{*}{$\begin{array}{l}\text { Std. } \\
\text { error of } \\
\text { estimate }\end{array}$} & \multicolumn{5}{|c|}{ Change statistics } \\
\hline & & & & & $\begin{array}{c}\text { R square } \\
\text { change }\end{array}$ & F change & df1 & df2 & $\begin{array}{c}\text { Sig. } F \\
\text { change }\end{array}$ \\
\hline 1 & $.854^{\mathrm{a}}$ & .730 & .710 & .44833 & .730 & 37.226 & 5 & 69 & .000 \\
\hline
\end{tabular}

a. Predictors: (Constant), consumer income, sport, respect of the environment, Digital marketing, exchange rate

Table 8: Coefficients ${ }^{a}$

\begin{tabular}{|c|c|c|c|c|c|c|}
\hline & \multirow[t]{2}{*}{ Model } & \multicolumn{2}{|c|}{$\begin{array}{l}\text { Unstandardized } \\
\text { coefficients }\end{array}$} & \multirow{2}{*}{$\begin{array}{c}\begin{array}{c}\text { Standardized } \\
\text { coefficients }\end{array} \\
\text { Beta }\end{array}$} & \multirow{2}{*}{$\mathbf{t}$} & \multirow{2}{*}{ Sig. } \\
\hline & & B & $\begin{array}{l}\text { Std. } \\
\text { error }\end{array}$ & & & \\
\hline \multirow[t]{6}{*}{1} & (Constant) & .464 & .268 & & 1.730 & .088 \\
\hline & Digital marketing & -.063 & .046 & -.095 & -1.362 & .178 \\
\hline & Respect environment & .024 & .043 & .037 & .551 & .584 \\
\hline & Exchange rate & .155 & .046 & .256 & 3.393 & .001 \\
\hline & Sport & -.038 & .044 & -.063 & -.861 & .392 \\
\hline & Consumer income & .786 & .080 & .760 & 9.818 & .000 \\
\hline \multicolumn{7}{|c|}{ a Dependent variable: destination preference } \\
\hline
\end{tabular}


H1: The most decisive criterion for visiting a country is respect for the environment is not supported. The most determining criterion according to the samples for choosing a destination country is consumer income $(67.7 \%)$, followed by the variable of exchange rate $(63.9 \%)$, then the digital marketing tools $(53.4 \%)$, followed by respect for the environment (38.6\%), and finally the sport variable $(33.3 \%)$.

H2: digital marketing factors positively affect tourism destination preference is not significant, since the $t$ of interviewees equals 1.362 , less than 2.76, and the relationship is not significant at the rate of significance equal to 0.178 (above the 5\% threshold). Similarly, H4: Sport positively affects tourist destination preference is not significant.

H3: Exchange rate positively affects tourist destination preference is significant, since the t of interviewees equals 3.393, less than 2.76. Similarly, hypothesis H5: Consumer income positively affects tourist destination preference is confirmed, since $\mathrm{t}$ is equals to 9.818 , less than 2.76 , and the relationship is significant, since the significance rate equals 0.000 , which is above the $5 \%$ threshold.

\section{CONCLUSION}

The digital revolution is radically changing the world we live in. The digital saturation of services has given communication companies the potential for exceptional capabilities (companies reach out to the individual in all aspects of their life). Tourism used to be based on pleasure. People see new places and enjoy themselves, but this has been changed due to digital marketing, and hence modern tools to advertise for tourism have been established. Based on the survey conducted, we conclude that the most decisive criterion for choosing to travel is consumer income $(67.7 \%)$. This explains why people who seek leisure take into account their budget in the first place. This is followed by the variable of exchange rate $(63.9 \%)$, then the digital marketing factors $(53.4 \%)$, respect for the environment $(38.6 \%)$ and finally the sport variable (33.3\%). Consumer income and exchange rate positively affect tourist destination preferences, while digital marketing, policy of respect for the environment adopted by the countries, and sport do not represent influential variables to attract tourists. 


\section{REFERENCES}

Adam, C., \& Cobham, D. (2007). Modelling multilateral trade resistance in a gravity model with exchange rate regimes. Centre for Dynamic Macroeconomic Analysis Conference Paper Series, 0702.

Algieri, B., \& Kanellopoulou, S. (2008). Determinants of demand for exports of tourism: An unobserved component model. Tourism and Hospitality Research, 9(1), 9-19.

Bashagi, A., \& Muchapondwa, E. (2009). What actions could boost international tourism demand for Tanzania?. Studies in Economics and Econometrics, 33(2), 59-75.

Behnassi, M. (2008). Tourisme durable: Fondements, indicateurs et apport au développement despays du Sud. Revue de Droit et de SciencesSociales, 96-120. Retrieved from https://cdurable.info/IMG/ pdf/Article-behnassi.pdf

Brüggemann, J., Hernández, M., Rodríguez, E., Soler, J., \& Tapper, R. (2001, November). Biodiversity and Tourism in the Framework of the Convention on biological Diversity: The case of the Tayrona National Park, Colombia. In Report of the Workshop at Cañaveral, Tayrona National Park.

Čerović, S., Vukadinović, P., \& Knežević, M. (2015). The influence of globalization on tourism and impact of tourism on other activities with an emphasis on greenfield investments in Tourism. In SITCON 2015-Singidunum International Tourism Conference (pp. 47-52). Singidunum University.

Chaiboonsri, C., Chaitip, P., \& Rangaswamy, N. (2009). Modelling international tourism demand in Thailand. Annals of the University of Petroşani, Economics, 9(3), 125-146.

Ellyard, P. (2006, December). Societal Changes - Impacts and Opportunities for Tourism. Paper presented at the Tourism Futures Conference: 21st Century Responses to 21st Century Realities, Melbourne. 
Femenia-Serra, F., Neuhofer, B., \& Ivars-Baidal, J. A. (2019). Towards a conceptualisation of smart tourists and their role within the smart destination scenario. The Service Industries Journal, 39(2), 109-133.

Gelter, H. (2017). Digital Tourism-An analysis of digital trends in tourism and customer digital mobile behavior. Report, Visit Artic Europe, Finland, May.

Gil-Pareja, S., Llorca-Vivero, R., \& Martínez-Serrano, J. A. (2007). The effect of EMU on tourism. Review of International Economics, 15(2), 302-312.

Gretzel, U., Sigala, M., Xiang, Z., \& Koo, C. (2015). Smart tourism: Foundations and developments. Electronic Markets, 25(3), 179-188.

Hooper, D. U., Chapin III, F. S., Ewel, J. J., Hector, A., Inchausti, P., Lavorel, S., ... \& Wardle, D. A. (2005). Effects of biodiversity on ecosystem functioning: A consensus of current knowledge. Ecological Monographs, 75(1), 3-35.

International Centre of Excellence in Tourism and Hospitality Education (THE-ICE). (2019). Our Vision, mission, history and constitution. Retrieved from https://the-ice.org/who-we-are/our-vision-missionhistory/

Kareem, O. I. (2008, July). A panel data analysis of demand for tourism in Africa. Paper presented at the $14^{\text {th }}$ African Econometric Society, Annual Conference, Cape Town, South Africa.

Khan, N., Hassan, A. U., Fahad, S., \& Naushad, M. (2020). Factors affecting tourism industry and its impacts on global economy of the world. Available at SSRN 3559353.

Lim, C. (1997). Review of international tourism demand models. Annals of Tourism Research, 24(4), 835-849.

Mohammed, K. S., Ouahrani, A., Bouknadil, M., \& Zenagui, S. (2015). Tourisme, croissance et taux de changé-Cas de l'Algérie: Une approche 
économétrique. International Journal of Innovation and Applied Studies, 13(4), 824-833.

Moreo, A., Green, A. J., \& O'Halloran, R. (2018). What certifications are important in the hospitality industry? Journal of Human Resources in Hospitality \& Tourism, 17(1), 121-135.

Pigeassou, C. (2002). Sport tourism, a growing sector: Issues and perspectives in France. In S. Gammon \& J. Kurtzman (Eds.), Sport tourism: Principles and practice (pp. 129-140). Eastbourne, UK: Leisure Studies Association.

Pigeassou, C. (2004). Le tourisme sportif: Une réalité sociale aux contours incertains. In C. Sobry (Ed.), Le tourisme sportif (pp. 33-66). Lille, France: Presses Universitaires du Septentrion.

Tertiary Education Quality and Standards Agency (TEQSA). (2019). What we do. Retrieved from https://www.teqsa.gov.au/what-we-do

Tse, R. Y., Hui, E. C. M., \& Chan, C. H. K. (2001). On the competitive land market: Evidence from Hong Kong. Review of Urban \& Regional Development Studies, 13(1), 46-61.

UNWTO. (2020). UNWTO World Tourism Barometer and Statistical Annex, 18(2). Retrieved from https://www.e-unwto.org/toc/ wtobarometereng/18/2

Yu, M., Li, Z., Yu, Z., He, J., \& Zhou, J. (2020). Communication related health crisis on social media: A case of COVID-19 outbreak. Current Issues in Tourism.

Zheng, Y., Goh, E., \& Wen, J. (2020). The effects of misleading media reports about COVID-19 on Chinese tourists' mental health: A perspective article. Anatolia, 31(2), 337-340. 